\title{
The main characteristics of atmospheric circulation over East-Central Europe from 1871 to 2010
}

\author{
Krzysztof Bartoszek ${ }^{1}$
}

Received: 21 July 2015/Accepted: 29 April 2016/Published online: 6 May 2016

(c) The Author(s) 2016. This article is published with open access at Springerlink.com

\begin{abstract}
The main objective of the paper concerns the determination of the annual and multi-annual variability of air flow over East-Central Europe in the period 1871-2010. Daily mean sea-level pressure and values of physical quantities provided the basis for distinguishing 27 circulation types, i.e., eight directional cyclonic, transitional, and anticyclonic types, and one non-directional cyclonic, anticyclonic, and an undefined type. Over the area of EastCentral Europe, the highest frequency is recorded for air flow from the western sector, with a maximum in the period from December to January. In spring, a higher than average frequency of cyclonic and easterly circulation is observed, and in summer-anticyclonic and northerly. Increased zonal circulation was recorded in the years 1910-1930, and particularly after 1970, and eastern at the end of the nineteenth century and in the 1930s and 1940s. An increase in the frequency of days with non-directional anticyclonic type and westerly air flow, and a simultaneous decrease in frequency of days with south-easterly and easterly circulation were observed throughout the study period. Among the three classes of circulation types, the highest persistence (particularly in winter) was recorded for anticyclonic types, i.e., when the high pressure system occurred over the Scandinavian Peninsula or East Europe.
\end{abstract}

Responsible editor: J.-F. Miao.

Krzysztof Bartoszek

k.bartoszek@umcs.pl

1 Department of Meteorology and Climatology, Maria CurieSklodowska University in Lublin, Al. Kraśnicka 2cd, 20-718 Lublin, Poland

\section{Introduction}

The location of East-Central Europe in mid-latitudes and between the Atlantic Ocean and Asian continent causes an advection of air masses with varied thermal and humidity characteristics. Atmospheric circulation in this part of Europe largely contributes to the spatial and temporal variability of meteorological elements, particularly in the cold part of the year (Bednorz 2002; Ustrnul 2006; Falarz 2007). In winters with a higher than the long-term frequency of easterly air flow, i.e., from the cooled interior of the Eurasian continent, considerable negative air temperature anomalies and long-term persistence of snow cover are typical. The strengthening of westerly zonal circulation and the related advection of air masses from the North Atlantic causes in the winter season in East-Central Europe the occurrence of types of weather usually observed there in late autumn or early spring (Jones et al. 1997; Sepp and Jaagus 2002).

The description of atmospheric circulation on various spatial scales is often based on calendars of circulation types (CTs). Differences between classifications of CTs concern the applied method, initial data, number of designated CTs, and size of the area they concern (Yarnal 1993; Huth et al. 2008). In general, such classifications can be divided into (1) manual, (2) automatic, and (3) mixed. In the first case, daily synoptic maps are analysed, where a given day is ascribed one of the pre-defined CTs based on the position of fronts and pressure systems. In this group, the best known ones include the Grossweterlagen classification developed for Central Europe (Baur 1937; Hess and Brezowsky 1977; Werner and Gerstengarbe 2010), the Lamb classification referring to the region of the British Islands (Lamb 1972) and the Vangengeim-Girs classification developed for the north-east part of Europe 
(Vangengeim 1935; Girs 1971). They were used in numerous climatological studies (e.g., Bárdossy and Caspary 1990; Keevallik et al. 1999; Kaszewski and Filipiuk 2003; Stehlík and Bárdossy 2003; Ustrnul 2006; Hoy et al. 2012, 2013). The assessment of the effect of atmospheric circulation on the variability of atmospheric conditions in Poland frequently involves the application of manual classifications by Osuchowska-Klein (1978) and Niedźwiedź (1981). An extensive review of research regarding the application of both of the classifications can be found in studies by Kaszewski $(2001,2012)$. The development of automatic classifications involves the use of relevant algorithms applied among others in the methods of principal component analysis (Huth 1996), cluster analysis (Zhang et al. 1997; Esteban et al. 2006) and neural networks (Schädler and Sasse 2006). Mixed classifications are usually based on the characteristics of daily mean sea-level pressure fields in association with air flow indices, whose values constitute the basis for distinguishing CTs (e.g., Jones et al. 1993; Buishand and Brandsma 1997; Ustrnul 1997; Goodess and Palutikof 1998; Demuzere et al. 2009; Piotrowski 2009). The latter approach was used in this paper because mixed classifications aim to harness the strengths of both techniques (manual and automated), as they are reproducible, yet allow the expertise of the researcher to be used to define the synoptic types (Lewis and Keim 2015). Moreover, mixed classifications have become more prevalent because they offer a way to analyse GCM output (Huth et al. 2008).

The objective is to present the detailed characteristics of the atmospheric circulation over East-Central Europe with a focus on the variability of air flow in the period 1871-2010 compared with the regime of air temperature and precipitation. The paper also extends knowledge about persistence, formation, as well as transformation of circulation types in this part of Europe.

\section{Materials and methods}

The classification of CTs used in this paper partially employs assumptions proposed by Lityński (1969) who divided CTs into three main classes, namely cyclonic, transitional, and anticyclonic. Polish literature on the subject includes a number of papers using the calendar of CTs by Lityński (e.g. Nowosad 2004; Żmudzka 2007; Łupikasza 2010; Ustrnul et al. 2010; Bartoszek and Węgrzyn 2011). The designation of the transitional class in the classification referring to the area of East-Central Europe seems justified due to the fact that air flow over the area is often determined by the co-occurrence of cyclonic and anticyclonic pressure systems.
The proposed classification of CTs based on daily mean sea-level pressure (MSLP) obtained from The Twentieth Century Reanalysis version 2 (20CRv2). The historical reanalysis dataset generated by NOAA Earth System Research Laboratory and the University of Colorado CIRES is a comprehensive global atmospheric circulation dataset spanning 1871-2010, assimilating only surface pressure and using monthly Hadley Centre SST and sea ice distributions (HadISST1.1) as boundary conditions (Compo et al. 2011). It should be mentioned that there may be data quality issues in the nineteenth century but this problem is also implicit in the early gridded chart products (Jones et al. 2013). In the study, MSLP values were derived firstly from a grid point located in East Poland ( $\varphi=51^{\circ} 15^{\prime} \mathrm{N}$ i $\lambda=22^{\circ} 50^{\prime} \mathrm{E}$; Fig. 1$)$ and covering the period 1871-2010. According to the assumption of Lityński (1969), they were ascribed to one of three classes distinguished by air pressure values below the long-term mean (cyclonic class), around the long-term mean (transitional class), and above the long-term mean (anticyclonic class). The threshold values for the classes amounted to the 33rd and 66th percentile of MSLP from the period 1871-2010, calculated separately for each month. According to Lityński, the probability density function of the atmospheric pressure value should be approximate to the normal distribution function. As shown in Fig. 2a, this assumption was met in the discussed case. For comparative purposes, a similar procedure was performed for total shear vorticity (estimated on the basis of Eq. 2), where the shapes of distribution curves were also studied (Fig. 2b). The contribution of days on which opposite classes

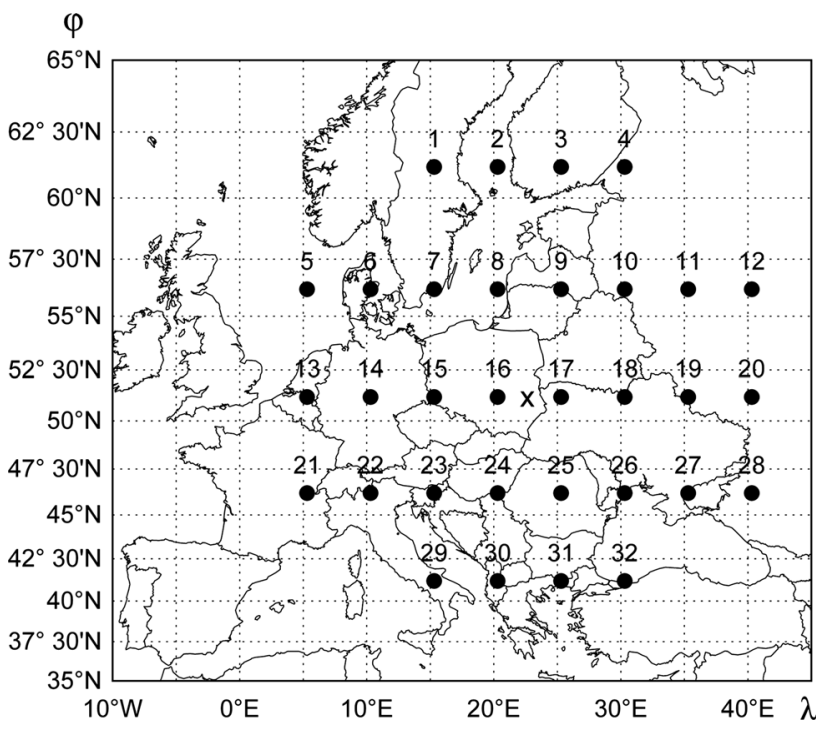

Fig. 1 Location of grid points used for the classification of circulation types over East-Central Europe with a central point at $51^{\circ} 15^{\prime} \mathrm{N}$ and $22^{\circ} 50^{\prime} \mathrm{E}$ 
(a)
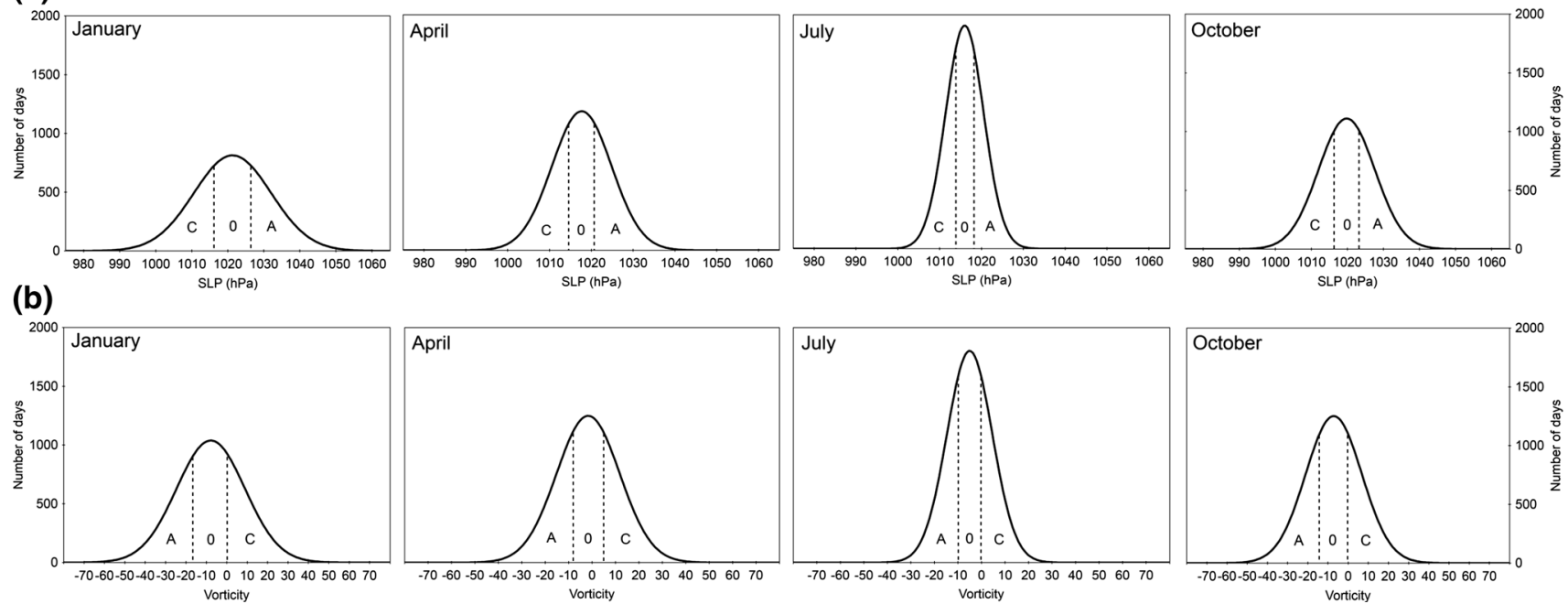

Fig. 2 Probability distribution curves of a mean daily sea-level pressure and $\mathbf{b}$ total shear vorticity in January, April, July and October at $\varphi=51^{\circ} 15^{\prime} \mathrm{N}$ and $\lambda=22^{\circ} 50^{\prime} \mathrm{E}$. Vertical dotted lines mark

boundaries between three classes of CTs, namely the cyclonic $(C)$, transitional $(O)$, and anticyclonic class $(A)$

(cyclonic/anticyclonic) occurred simultaneously amounted to only $1.1 \%$. However, in the case of total shear vorticity, for the majority of the year it was not only the anticyclonic class that entirely found itself on the side of negative values but also the transitional class (Fig. 2b). As a result, the determination of thresholds for classes of CTs involved the application of MSLP.

The determination of the direction of air flow and nondirectional patterns (pure cyclonic/anticyclonic and undefined type) was based on procedures defined by Jenkinson and Collinson (1977) and Jones et al. (1993). This method relies on a set of indices related to the velocity and direction of geostrophic flow, as well as total shear vorticity, calculated using a gridded data set of sea-level pressure. This method has been used a number of times for the assessment of the effect of atmospheric circulation on the variability of selected meteorological elements in various regions of Europe (e.g., Chen 2000; Trigo and Da Camara 2000; Linderson 2001; Post et al. 2002; Piotrowski 2009). In this paper, daily gridded fields $\left(5^{\circ} \times 5^{\circ}\right.$ longitude-latitude) of mean sea-level pressure were used over an area defined from $5^{\circ} 20^{\prime}$ to $40^{\circ} 20^{\prime} \mathrm{E}$ and from $41^{\circ} 15^{\prime}$ to $61^{\circ} 15^{\prime} \mathrm{N}$ (Fig. 1). This provided the basis for the computation of circulation indices expressed by the following equations:

Resultant flow $(F)$

$F=\sqrt{W^{2}+S^{2}}$

Total shear vorticity $(V)$

$V=V W+V S$

where the components can be obtained based on the equations as follows:

Westerly flow $(W)$

$$
\begin{aligned}
W= & 0.25 \times\left(p_{23}+p_{24}+p_{25}+p_{26}\right)-0.25 \\
& \times\left(p_{7}+p_{8}+p_{9}+p_{10}\right)
\end{aligned}
$$

Southerly flow $(S)$

$$
\begin{aligned}
S= & 1.596 \times\left[0.125 \times\left(p_{10}+2 \times p_{18}+p_{26}+p_{9}\right.\right. \\
& \left.+2 \times p_{17}+p_{25}\right)-0.125 \times\left(p_{7}+2 \times p_{15}\right. \\
& \left.\left.+p_{23}+p_{8}+2 \times p_{16}+p_{24}\right)\right]
\end{aligned}
$$

Westerly shear vorticity $(V W)$

$$
\begin{aligned}
\mathrm{VW}= & 1.079 \times\left[0.25 \times\left(p_{29}+p_{30}+p_{31}+p_{32}\right)-0.25\right. \\
& \left.\times\left(p_{15}+p_{16}+p_{17}+p_{18}\right)\right]-0.938 \times[0.25 \\
& \left.\times\left(p_{15}+p_{16}+p_{17}+p_{18}\right)-0.25 \times\left(p_{1}+p_{2}+p_{3}+p_{4}\right)\right]
\end{aligned}
$$

Southerly shear vorticity $(V S)$

$$
\begin{aligned}
\mathrm{VS}= & 1.273 \times\left[0.125 \times\left(p_{12}+2 \times p_{20}+p_{28}+p_{11}+2\right.\right. \\
& \left.\times p_{19}+p_{27}\right)-0.125 \times\left(p_{10}+2 \times p_{18}+p_{26}+p_{9}\right. \\
& \left.\left.+2 \times p_{17}+p_{25}\right)\right]-1.273 \times\left[0.125 \times\left(p_{8}+2 \times p_{16}\right.\right. \\
& \left.\left.+p_{24}+p_{7}+2 \times p_{15}+p_{23}\right)\right]-0.125 \times\left(p_{6}+2\right. \\
& \left.\left.\times p_{14}+p_{22}+p_{5}+2 \times p_{13}+p_{21}\right)\right]
\end{aligned}
$$

The grid points from $p_{1}$ to $p_{32}$ correspond to sea-level pressure values $(\mathrm{hPa})$. The flow units $(F)$ are geostrophic, expressed as $\mathrm{hPa}$ per $10^{\circ}$ latitude at $51^{\circ} 15^{\prime} \mathrm{N}$; each unit is equivalent to $0.62 \mathrm{~ms}^{-1}$. The geostrophic vorticity $(V)$ units are expressed as $\mathrm{hPa}$ per $10^{\circ}$ latitude also at $51^{\circ} 15^{\prime} \mathrm{N}$; 
1 unit is equivalent to $0.7 \times 10^{-6} \mathrm{~s}^{-1}$. The direction of flow $(D)$ has been determined using westerly $(W)$ and southerly flow $(S)$ :

$D=\arctan (S / W), \quad$ if $W \leq 0$

$D=\arctan (S / W)+180, \quad$ if $W>0$

The cyclonic non-directional type $(C)$ included days, when $|V|>2 F$ (if $V>0$ ), and the anticyclonic non-directional type (A), when $V<-10$ and $V / F<-4$. The undefined type (X) was determined for cases if $F<2 \mathrm{~m} / \mathrm{s}$ and $|V|<12$. The rest of the cases were distributed between 24 directional CTs referring to the three classes proposed by Lityński (anticyclonic, transitional and cyclonic) and eight directions (north, N; northeast, NE; east, E; southeast, SE; south, S; southwest, SW; west, W; northwest, NW). This way, 27 CTs were obtained, i.e., eight directional cyclonic, transitional, and anticyclonic types, and one non-directional cyclonic, anticyclonic, and an undefined type (Table 1).

The persistence of particular CTs (in days) was analysed following the preparation of a series of data for each of them, referring to the duration of particular sequences of days with a given type. Values of quantiles of persistence of CTs were calculated based on the Weibull distribution the parameters of which were determined by means of the maximum likelihood method:

$x=\alpha+\beta(\ln p)^{\frac{1}{\lambda}}$

where $x$ value of quantile, $\alpha$ location parameter, $\beta$ scale parameter, $\lambda$ shape parameter, $p$ probability of exceedance.

Proceeding similarly to Kyselý and Domonkos (2006), each event (a sequence of days classified with the same circulation type) is taken into account one by one in order to present the long-term variability of the mean residence time of the circulation patterns.
The relationships between atmospheric circulation and climate between 1951 and 2010 are examined using daily sum of precipitation and mean air temperature values from the E-OBS dataset (Haylock et al. 2008). A gridded data set is based on data which have been gathered during the European Climate Assessment and Dataset project. Analysis is based on averaged data from the five grid points. They are placed in the area of interest, i.e., nearby meteorological stations located in Brest (Belarus), Lublin (Poland), Lviv (Ukraine), Sandomierz (Poland) and Warsaw (Poland).

The determination of the statistical significance of trends involved the application of the non-parametric MannKendall test (Kendall 1975). The magnitude of changes in the annual number of days with CTs was determined by Sen's method (1968). In order to identify periods with a considerable increase or decrease in the frequency of air flow from a given direction, the magnitude of trends was determined for each of the 30-year moving periods within the period from 1871 to 2010 .

\section{Results}

\subsection{Direction of air flow over East-Central Europe in months}

Over the area of East-Central Europe, December and January are distinguished by a considerable prevalence of westerly and south-westerly air flow, as well as a low frequency of days with northerly, north-easterly, and easterly circulation (Fig. 3). This is presumably the result of the main centres of atmospheric activity in the area of north-east Atlantic at this time of the year, i.e., the Icelandic Low and Azores High. Their geographical location causes the occurrence of westerly zonal circulation over the

Table 1 Classification of circulation types over East Central Europe

\begin{tabular}{|c|c|}
\hline Symbols & Description \\
\hline $\begin{array}{l}\text { Nc, NEc, Ec, SEc, Sc, SWc, Wc, } \\
\text { NWc }\end{array}$ & Directional cyclonic types (strong advection during cyclonic circulation) \\
\hline $\begin{array}{l}\text { No, NEo, Eo, SEo, So, SWo, } \\
\text { Wo, NWo }\end{array}$ & $\begin{array}{l}\text { Directional transitional types (strong advection with a contribution of both low and } \\
\text { high pressure systems) }\end{array}$ \\
\hline $\begin{array}{l}\text { Na, NEa, Ea, SEa, Sa, SWa, Wa, } \\
\text { NWa }\end{array}$ & Directional anticyclonic types (strong advection during anticyclonic circulation) \\
\hline $\mathrm{C}$ & Cyclonic non-directional type (high positive total shear vorticity values over the study area) \\
\hline A & $\begin{array}{l}\text { Anticyclonic non-directional type (high negative total shear vorticity values and weak geostrophic wind } \\
\text { velocity over the study area) }\end{array}$ \\
\hline $\mathrm{X}$ & Undefined non-directional type (low total shear vorticity values and weak geostrophic wind velocity) \\
\hline
\end{tabular}



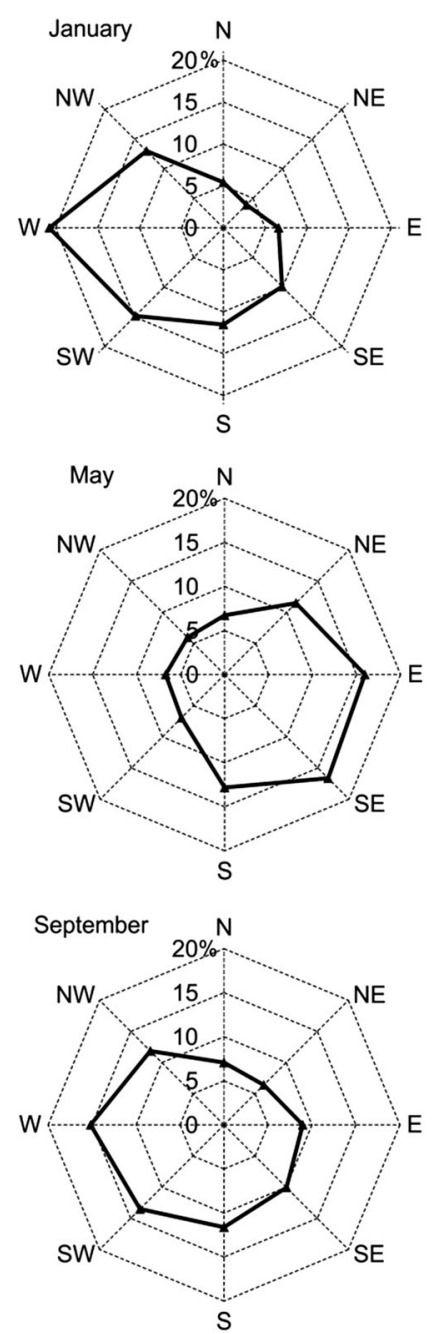
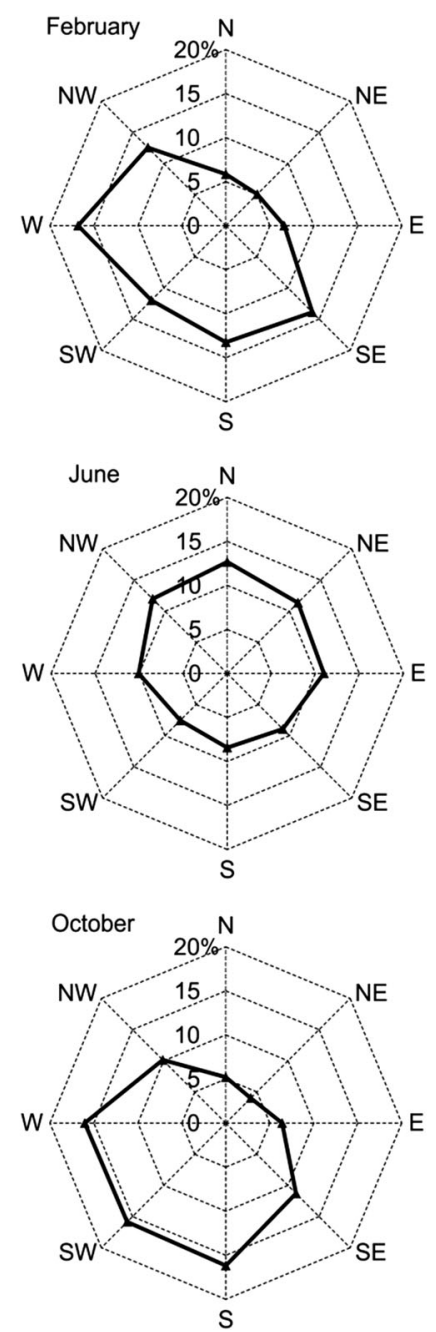
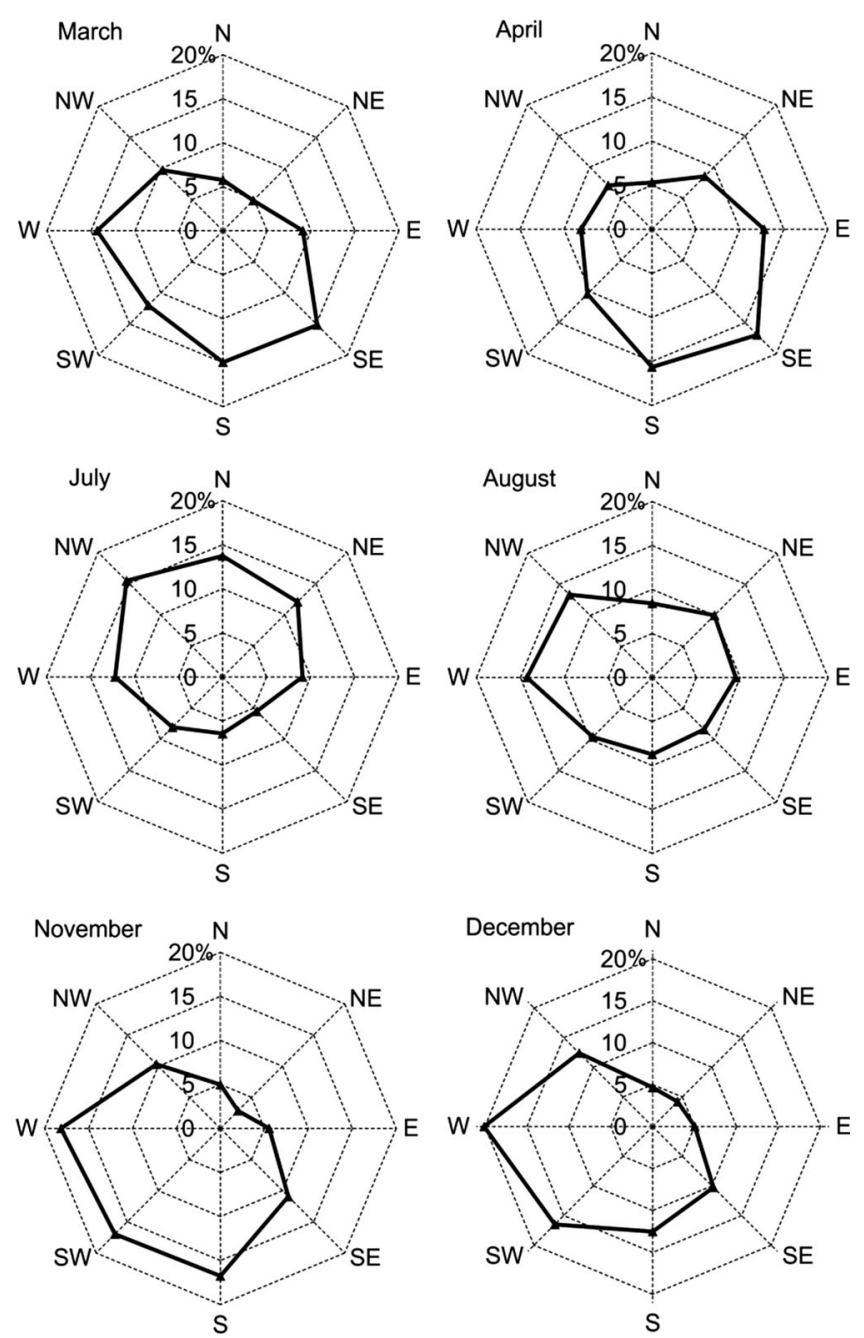

Fig. 3 Mean monthly frequency of days with different directions of air flow over East-Central Europe (1871-2010). The values are calculated based on the number of days with directional CTs

European continent, particularly strong in years when the difference in atmospheric pressure between these two areas of the Atlantic is higher than average (Osborn 2006). From February to May over East-Central Europe, gradual weakening of zonal circulation occurs, and southerly, south-easterly, and easterly air flow prevails (Fig. 3). In June and July, an increase in the frequency of circulation with a northern component is manifested. This may be partly caused by the centre of the Azores High shifted towards the north-east in comparison to winter (Hurrell et al. 2003). From August to November, an increase in the frequency of westerly, south-westerly, and southerly air flow is observed again, as well as a considerable decrease in the northerly, north-easterly, and easterly. Out of all the directions, westerly circulation is distinguished by the highest mean number of days in the year, and north-easterly and northerly - the lowest. In the period 1871-2010, the highest variability of annual frequency was recorded for easterly air flow, and the lowest for south-westerly advection (coefficient of variation is equal to 30.5 and $19.6 \%$, respectively).

\subsection{Frequency of circulation types and their influence on temperature and precipitation}

In the period 1871-2010, among all of the CTs, the highest mean number of days in a year was recorded for nondirectional anticyclonic type A (Figs. 4, 5; Table 2). Its highest frequency was recorded in summer, while the lowest in spring. High frequency was also observed for non-directional cyclonic type $\mathrm{C}$ (a spring maximum and an evident minimum in summer), as well as directional types with air flow from the western sector (a winter maximum and minimum in spring; Fig. 6). Circulation types with 

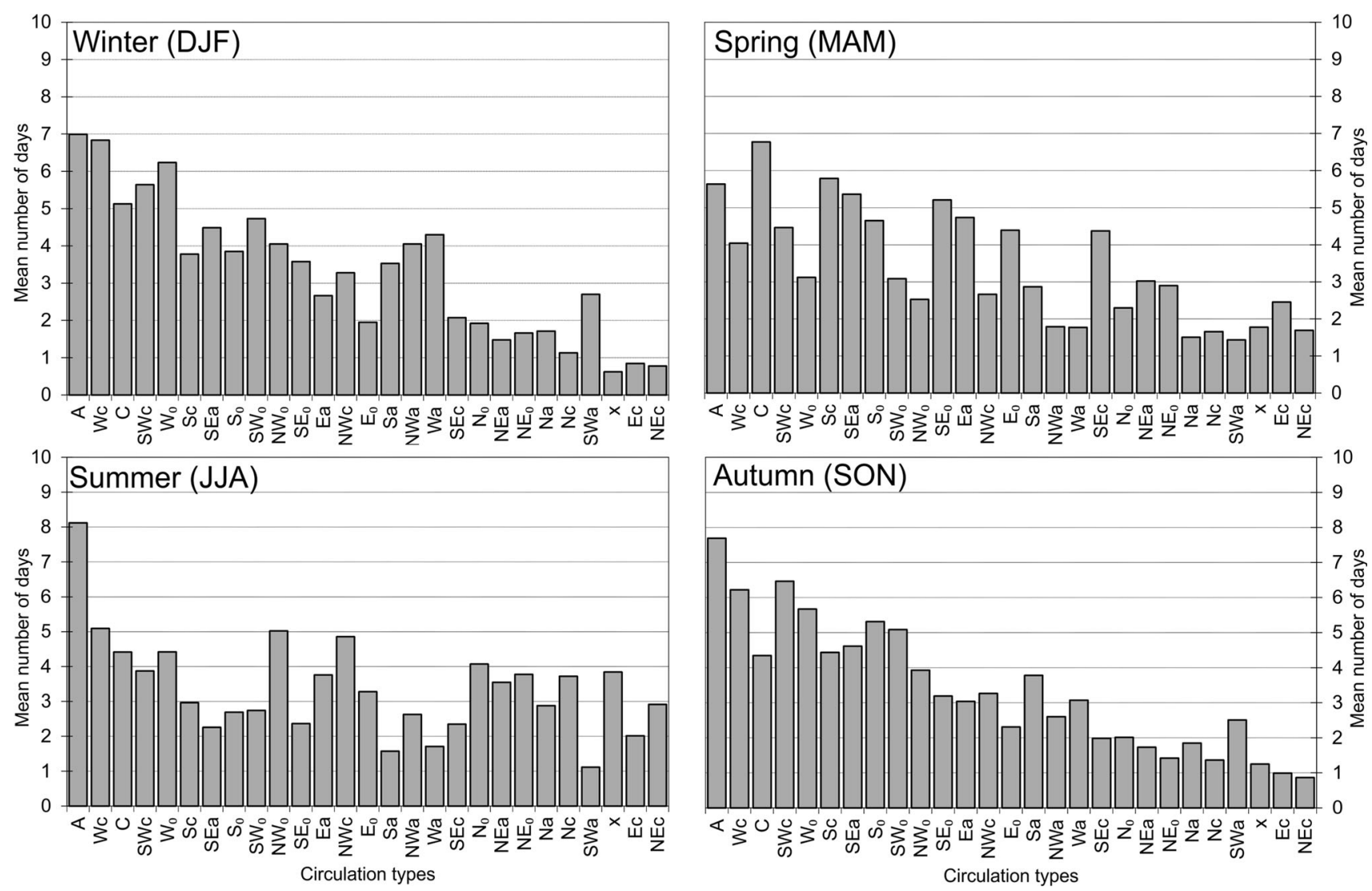

Fig. 4 Mean seasonal number of days with CTs over East-Central Europe (1871-2010)

northerly and north-easterly air flow were recorded the most seldomly (an evident maximum in summer), as well as non-directional undefined type $\mathrm{X}$ (Table 2).

The prevalence of directional anticyclonic over cyclonic types was the most evident in the case of north-easterly, easterly, and south-easterly air flow. The opposite relationship was seen for southerly, south-westerly, westerly, and north-westerly advection (Table 2). A higher frequency of directional transitional than cyclonic and anticyclonic types was only recorded in the case of northwesterly and northerly air flow.

The seasonal cycle of air temperature over East-Central Europe depends to a large extent on the direction of air flow, while precipitation on the predominance of cyclonic or anticyclonic circulation (Fig. 7). In winter, the highest positive temperature anomalies relate to air flow from the western sector, while the negative ones to eastern circulation patterns. In all other seasons, higher than normal air temperatures are observed during air flow from the southern sector, and lower values are associated with the northern air advection. In the case of precipitation, clear positive anomalies can be seen in all seasons during cyclonic circulation patterns. Among all of the types, the highest positive anomalies of precipitation sums relate to type $\mathrm{C}$ and $\mathrm{NEc}$, while negative ones to type A, SEa, Sa and SWa (Fig. 7).

\subsection{Formation and transformation of circulation types}

Information from what other types a given circulation type develops, and on the frequency of transformation of a particular type into the remaining ones not only permits the determination of changes occurring in the pressure field over a given area, but can also be of importance for forecasting (Piotrowski 2009). For example, occurrence of Ea, $\mathrm{SEa}$, and Sa types was a continuation of the previous day's weather type in 35-45\% of cases. Type Ea (the centre of a high pressure system north or north-east of the study area) was usually transformed into type SEa, and then into Sa, reflecting the location of the high pressure system over East Europe. Type A with somewhat higher frequency developed from types NEa, Na, and NWa (high pressure system over West and North-West Europe), and was usually transformed into types $\mathrm{Sa}$, SWa, and Wa (the centre of a high pressure system south and south-east of East-Central Europe).

The prevalence of westerly zonal circulation in this part of Europe was more evidently reflected by the order of formation of directional cyclonic types. One of the most frequently occurring types, i.e., SWc (centre of low pressure system over the British Isles) was usually transformed 
Fig. 5 The eight most frequent circulation patterns over EastCentral Europe for the 1871-2010 period
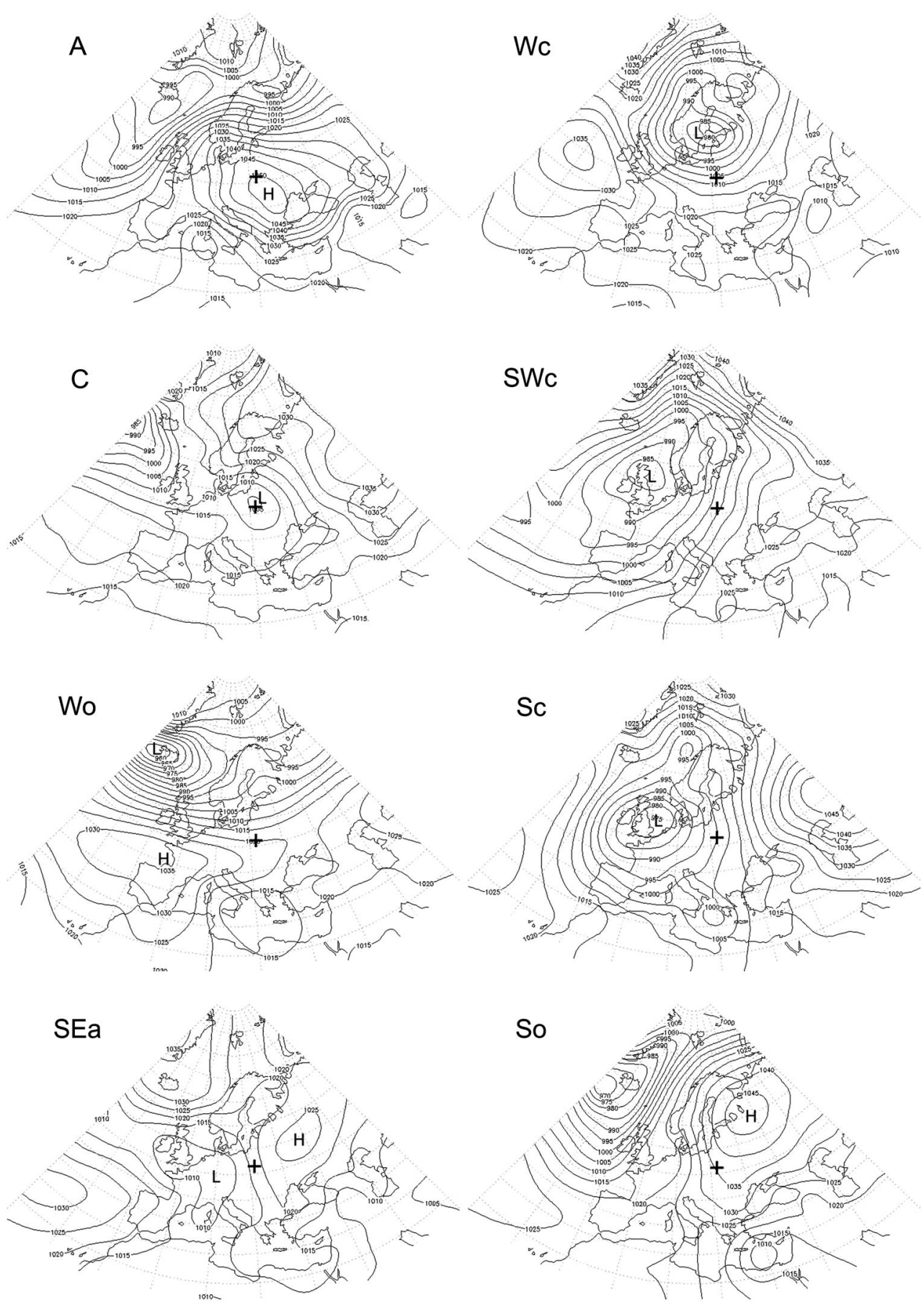

into type Wc, and then into NWc (centre of low over North Europe). Equally high frequency was recorded in the case of transformation of the mentioned typed in the opposite order. This may result from a series of low pressure systems moving from west to east.

Type Sc (the centre of a low pressure system over West Europe) was one of the most persistent cyclonic types. Non-directional type $\mathrm{C}$ often evolved from it, and in approximately $10 \%$ of cases - the rarely occurring type
SEc. The continuation of transformation of type SEc into other rarely occurring CTs, i.e. Ec, NEc, and Nc (centre of the low pressure system south, south-east, and east of Poland, respectively) can to a certain degree correspond with the $\mathrm{Vb}$ van Bebber track, reflecting the movement of low pressure systems from the Mediterranean Sea towards East Europe. In the summer period, this type of system frequently results in the appearance over Central Europe of persistent rainfalls and floods (Blöschl et al. 2013). Type C 
Table 2 Characteristics of the frequency of circulation types over East Central Europe from 1871 to 2010

\begin{tabular}{|c|c|c|c|c|c|c|c|}
\hline $\begin{array}{l}\text { Circulation } \\
\text { types }\end{array}$ & $\begin{array}{l}\text { Mean number } \\
\text { of days per } \\
\text { year }\end{array}$ & $\begin{array}{l}\text { Maximum } \\
\text { number of days } \\
\text { (year) }\end{array}$ & $\begin{array}{l}\text { Minimum } \\
\text { number of days } \\
\text { (year) }\end{array}$ & $\begin{array}{l}\text { The longest } \\
\text { sequence in days } \\
\text { (period) }\end{array}$ & $\begin{array}{l}\text { Month with } \\
\text { maximum of } \\
\text { frequency }\end{array}$ & $\begin{array}{l}\text { Month with } \\
\text { minimum of } \\
\text { frequency }\end{array}$ & $\begin{array}{l}\text { Standard } \\
\text { deviation }\end{array}$ \\
\hline $\mathrm{Nc}$ & 7.9 & $21(1988)$ & $1(1942 / 1963)$ & 7 (16-22.06.1894) & July & December & 3.5 \\
\hline $\mathrm{N}_{0}$ & 10.3 & $19(1890 / 1911)$ & $2(1912)$ & $5(2-6.07 .1972)$ & July & December & 3.6 \\
\hline $\mathrm{Na}$ & 7.9 & 24 (1959) & $1(1877 / 1974)$ & $7(17-23.06 .1941)$ & June & March & 3.7 \\
\hline NEc & 6.3 & 19 (1906) & 0 (1994) & ${ }^{7}(28.05-3.06 .1891)$ & July & November & 3.3 \\
\hline $\mathrm{NE}_{0}$ & 9.8 & $21(2004)$ & $1(1923 / 1942)$ & $5(1-5.07 .1930)$ & July & November & 4.0 \\
\hline $\mathrm{NEa}$ & 9.8 & $26(1975)$ & 1 (1916) & $6(20-25.05 .1919)$ & May & November & 4.1 \\
\hline Ec & 6.3 & 19 (1939) & $0(1872 / 1963)$ & $5(14-18.04 .2005)$ & May & November & 3.3 \\
\hline $\mathrm{E}_{0}$ & 11.9 & 25 (1939) & 2 (1949) & 7 (12-18.05.1894) & May & November & 4.7 \\
\hline $\mathrm{Ea}$ & 14.2 & $32(1934)$ & $0(1878)$ & $10(1-10.05 .1971)$ & May & December & 6.1 \\
\hline $\mathrm{SEc}$ & 10.8 & $23(1876)$ & $1(1920 / 1967)$ & 7 (15-21.05.1949) & May & July & 4.9 \\
\hline $\mathrm{SE}_{0}$ & 14.4 & $30(1914 / 1918)$ & $3(1957 / 1974)$ & $8(3-10.03 .1946)$ & April & July & 5.4 \\
\hline SEa & 16.7 & 39 (1920) & $4(1925 / 1983)$ & $14(12-25.03 .1996)$ & March & July & 7.4 \\
\hline Sc & 17.0 & 38 (1934) & $6(1894)$ & $8(8-15.04 .1899)$ & April & July & 6.2 \\
\hline $\mathrm{S}_{0}$ & 16.4 & $34(1954)$ & $4(1875)$ & $7(9-15.12 .1882)$ & October & July & 5.8 \\
\hline $\mathrm{Sa}$ & 11.8 & $32(1920 / 1953)$ & $3(1873)$ & $10(18-27.10 .1901)$ & November & July & 4.7 \\
\hline SWc & 20.4 & 35 (1954) & $6(1953)$ & $\begin{array}{l}8 \\
\quad(29.11-6.12 .1909)\end{array}$ & October & May & 5.6 \\
\hline $\mathrm{SW}_{0}$ & 15.6 & $34(1961)$ & $6(1937 / 1946)$ & $12(8-19.01 .2008)$ & December & May & 5.1 \\
\hline SWa & 7.8 & $19(1914 / 1964)$ & $0(1922)$ & $6(7-12.12 .1964)$ & November & May & 3.8 \\
\hline Wc & 22.2 & $45(1925)$ & $9(1896)$ & $8(16-23.01 .1956)$ & January & May & 6.2 \\
\hline $\mathrm{W}_{0}$ & 19.5 & $43(1873)$ & 7 (1959) & $12(6-17.01 .1873)$ & January & April & 6.1 \\
\hline Wa & 10.9 & $26(1978)$ & $3(1872 / 1981)$ & $6(16-21.12 .1932)$ & December & May & 4.5 \\
\hline NWc & 14.0 & 25 (2007) & 3 (1996) & $8(3-10.07 .1908)$ & July & May & 4.4 \\
\hline $\mathrm{NW}_{0}$ & 15.5 & 35 (1971) & $6(1877 / 1963)$ & $6(19-24.07 .1990)$ & July & May & 5.1 \\
\hline NWa & 11.1 & $29(1961)$ & $2(1872 / 1912)$ & $7(15-21.02 .1961)$ & December & April & 5.0 \\
\hline A & 28.4 & $54(1964)$ & $13(1882)$ & $8(9-16.07 .1928)$ & August & May & 7.5 \\
\hline $\mathrm{C}$ & 20.6 & $38(1960)$ & $6(1942)$ & $7(24-30.08 .1920)$ & May & September & 6.1 \\
\hline$X$ & 7.5 & $16(1937 \backslash 1941)$ & $0(1969 / 1993)$ & $5(12-16.08 .1932)$ & July & December & 3.1 \\
\hline
\end{tabular}

was usually transformed into situations from the centre of low pressure system located east or north-east of the analysed area (NWc and $\mathrm{Nc}$ ).

Transitional types usually developed and were transformed into anticyclonic or cyclonic types with the same direction of air flow. In the case of north-westerly, northerly, and north-easterly air flow, transitional types developed evidently more frequently from cyclonic types, and in the case of south-easterly, southerly, and south-westerly air flow, from anticyclonic types. Among all of the transitional types, type NWo stood out, usually developing from and evolving into type Wo.

The highest variability of the discussed characteristic concerned the undefined type $\mathrm{X}$. It developed from other non-directional types with somewhat higher frequency, i.e., type $\mathrm{C}$ and $\mathrm{A}$ and from types with southerly air flow. It was the most frequently transformed into types with a northerly component and into type A.

\subsection{Persistence of circulation types}

It is important to know the residence times of the circulation patterns over the area of interest because the enhanced persistence of atmospheric circulation patterns may affect the occurrence of surface climatic extremes (Kyselý 2007). Among the three classes of CTs, the highest persistence was observed for anticyclonic, and the lowest for transitional types. It reflects fact that, in general, anticyclones are more stable both in time and space that cyclones. In the anticyclonic class, a significant variability occurred between particular CTs, i.e., types $\mathrm{Ea}, \mathrm{SEa}$, and $\mathrm{Sa}$ (the centre of a high pressure system north-east and east of the 

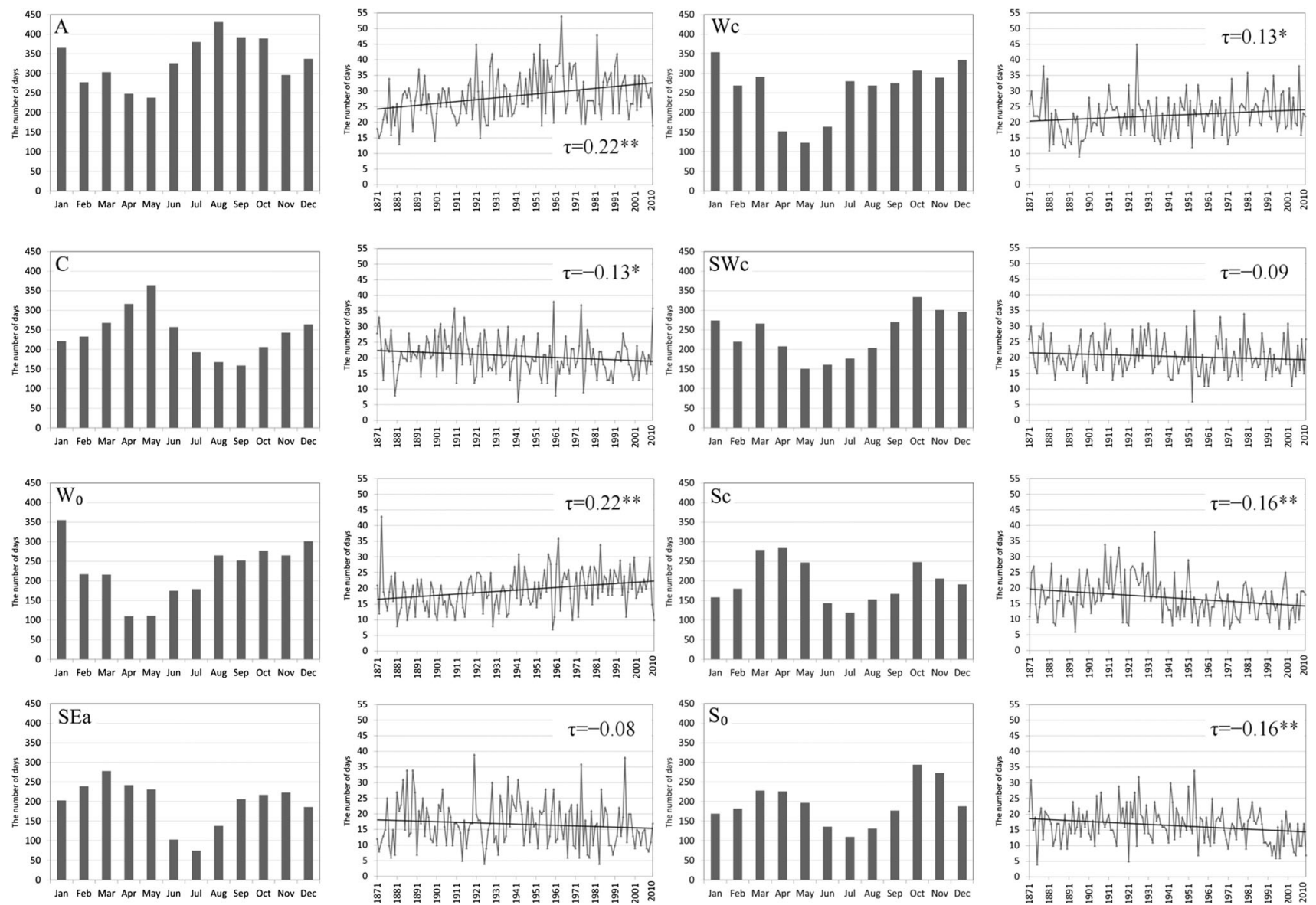

Fig. 6 Annual distribution and 140-year variability of the number of days with most frequent circulation types over East-Central Europe. *, **The level of significance for the Kendall's tau trend test, at $p<0.05, p<0.01$, respectively

study area) were distinguished by considerable persistence, and types SWa, Wa, NWa, and $\mathrm{Na}$ (the centre of a high pressure system south and west of Central-West Europe) were short in duration (Fig. 8). In the remaining two classes, the differences between CTs were considerably lower. In the cyclonic class, situations with south-westerly and westerly air flow were more persistent (the centre of a low pressure system west and north of the analysed area), and in the transitional class-from north-easterly to southerly air flow (Fig. 8). In the period 1871-2010, the longest sequence of 14 consecutive days was recorded with type SEa (12-25.03.1996).

A higher persistence of anticyclonic than cyclonic types was observed in all seasons of the year in the case of northeasterly to south-easterly air flow, as opposed to the case of south-westerly and westerly air flow (not shown). In the summer period, there was a considerably shorter duration of types with southerly air flow than in the remaining seasons of the year, and a longer period of northerly and north-easterly advection. In winter, a very high persistence of types Ea, SEa, and Sa occurred, i.e., during the persistence of the high pressure system over the Scandinavian Peninsula and East Europe. The shortest sequences of days with type A occurred in spring, and the longest in autumn and winter. Type $\mathrm{C}$ showed the highest persistence in summer, and the lowest in autumn and winter. Among all of the CTs, the shortest duration concerned the undefined type X.

The shift towards lower persistence is statistically significant in type $\mathrm{C}$ and types with south-easterly and southerly air flow was observed during the whole analysed period (Fig. 9). In contrast, an increase in the mean lifetime of type A, Wc and Wo was found. It should be noted that Werner et al. (2000), as well as Kyselý and Domonkos (2006) reported a more sharp rise in the residence times of the zonal circulation over Central Europe in the 1980s and 1990s. In conclusion, it can be clearly seen that long-term changes in the persistence of atmospheric circulation are associated with the trends in the frequency of circulation types through the analysed period. 
Fig. 7 Deviation from seasonal a mean air temperature and b mean precipitation for directional cyclonic (dotted line), transitional (dashed line) and anticyclonic circulation types (solid line), estimated from daily values for 1951-2010 (a)
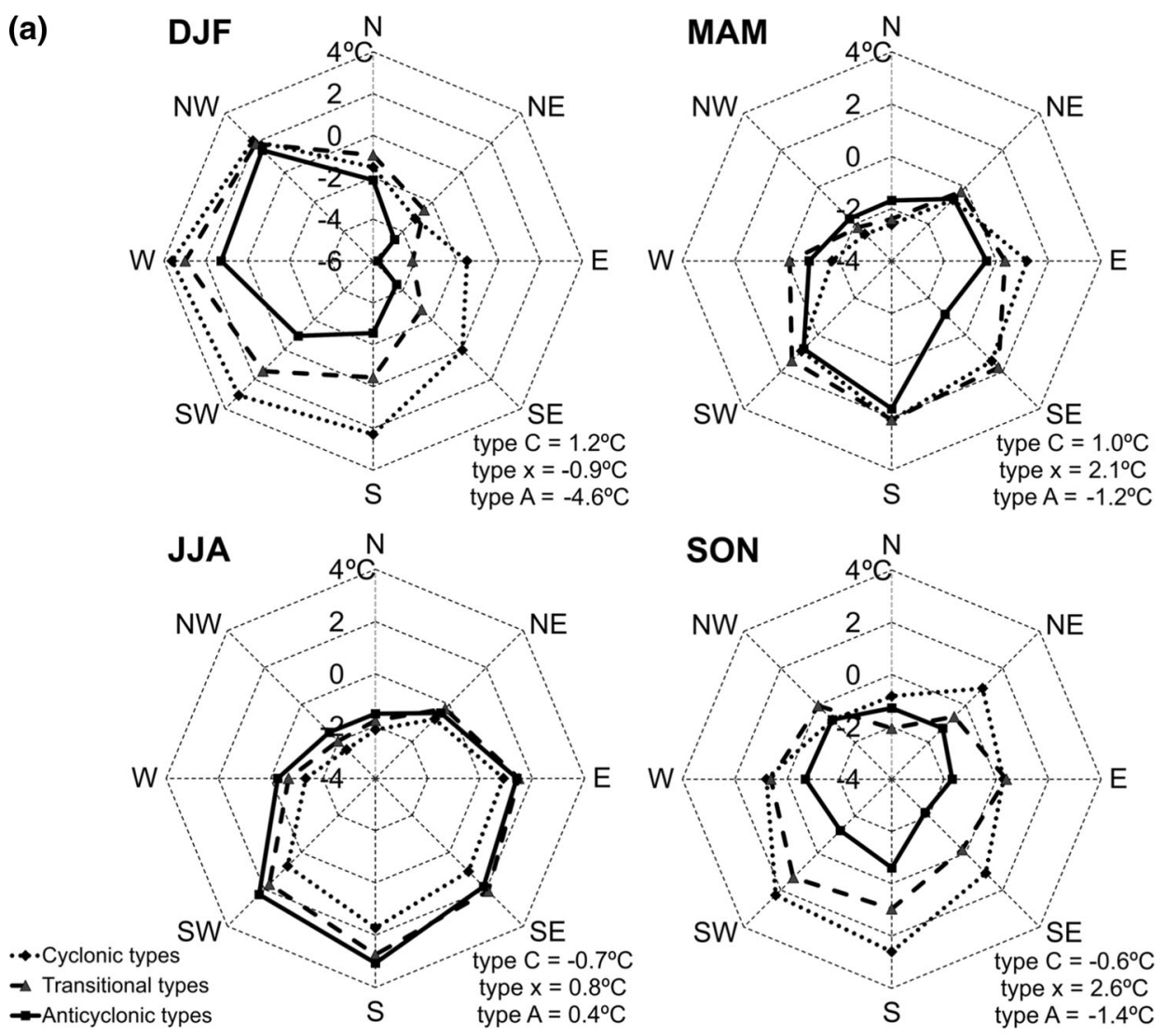

(b)
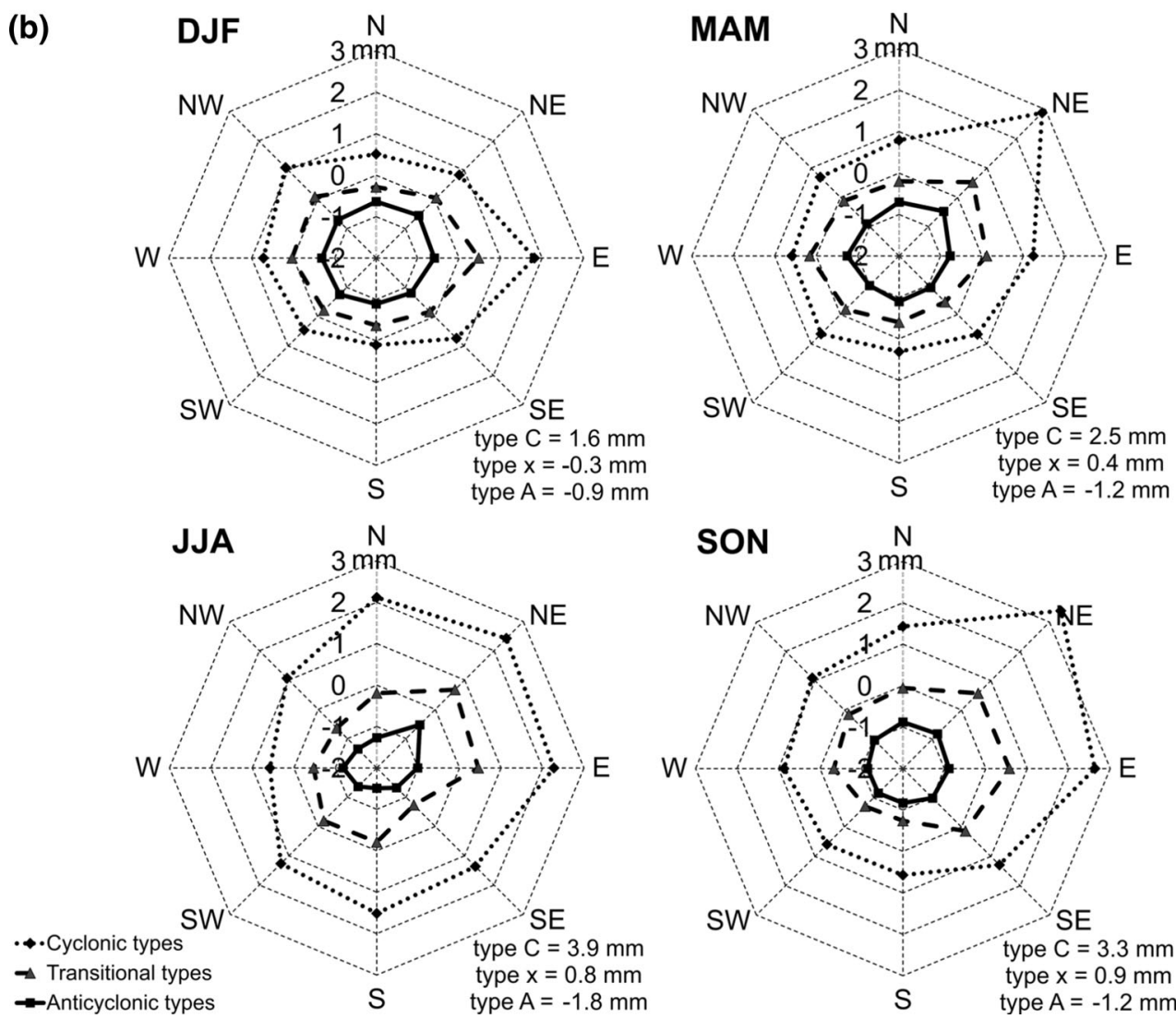
Fig. 8 Length of sequences of days with an exceedance probability of $5 \%$ for cyclonic, transitional, anticyclonic and all directional types
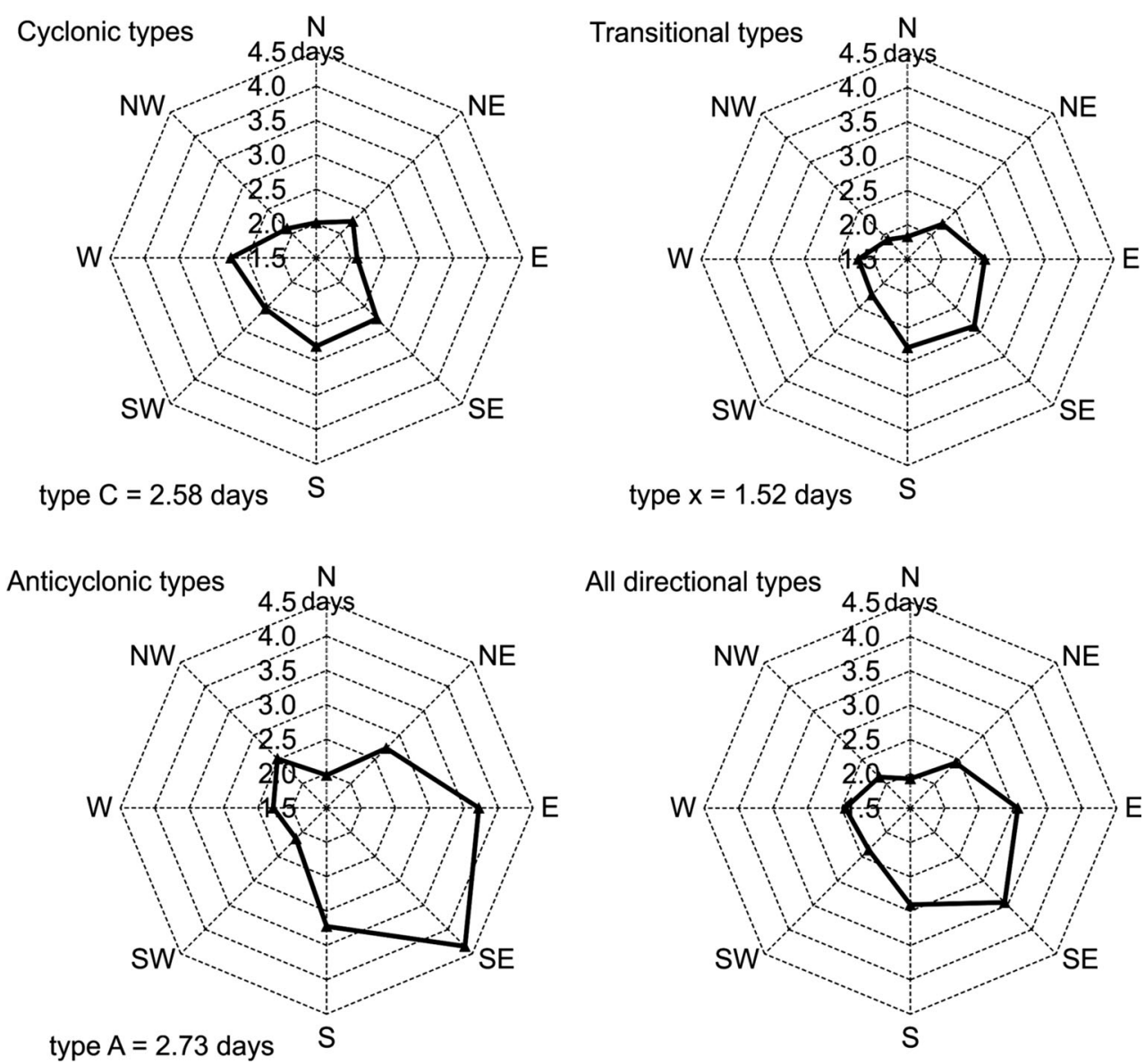

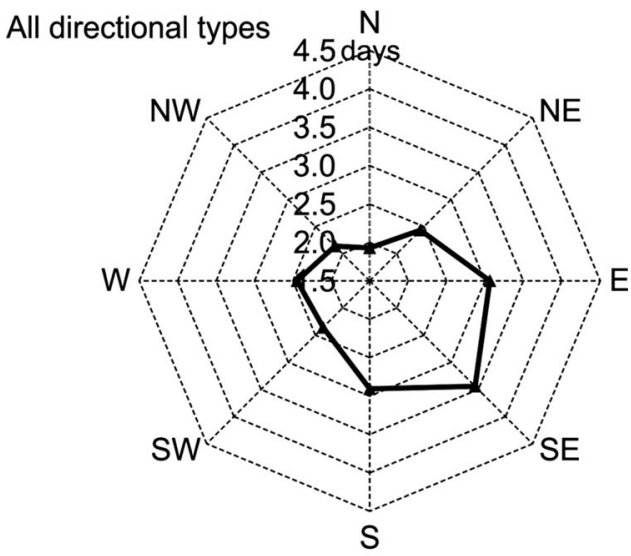

\subsection{Long-term variability of atmospheric circulation and the relationship with temperature and precipitation in the last decades}

A detailed analysis of the multi-annual variability of atmospheric circulation involves the determination of the magnitude of trends for each of the 30-year moving periods within 1871-2010, referring both to the annual number of days with air flow from a given direction, as well as nondirectional types A and C (Fig. 10). Anticyclonic non-directional type A was distinguished by a noticeably higher frequency in the 1950s and 1960s and at the turn of the 1980s and 1990s, and lower in the 1970s and in the period between 1900 and 1915. The strongest increasing trend occurred in the mid-twentieth century (4.6 days/10 years in the period 1936-1965), and decreasing trend at the turn of the nineteenth and twentieth century ( 3.5 days/10 years in the period 1884-1913) and in the 1970s (4.3 days/10 years in the period 1949-1978). A lower range of variations from the long-term mean concerned cyclonic non-directional type $\mathrm{C}$ with maximum frequency in the first decades of the twentieth century (increase by 3.1 days/10 years in the period 1881-1910), and the highest decrease in the frequency of days was recorded much later, i.e., in the period 1902-1931 (3.2 days/10 years).

The longest period with northerly air flow frequency lower than the long-term mean was recorded over the first three decades of the twentieth century, and its highest decrease occurred in the years 1898-1927 (3.6 days/ 10 years). Increased northerly air flow was observed from the 1980s to the end of the first decade of the 21 st century, whereas the highest increase in the frequency occurred in the years 1963-1992 (3.3 day/10 years). The course of the number of days with north-easterly air flow showed slight variations from the mean value (Fig. 10). The maximum increase in frequency of days occurred in the years 1960-1989 (3.5 days/10 years), with a decrease between 1890 and 1919 (4.0 days/10 years). A considerably higher variability in the number of days concerned easterly air flow with a maximum at the turn of the 1930s and 1940s, and minimum in the 1980s. At the end of the study period, a very evident increase in frequency of days with easterly circulation occurred, reaching 7.5 days/10 years in the period 1981-2010. A decreasing contribution throughout the study period was recorded in the case of south-easterly 

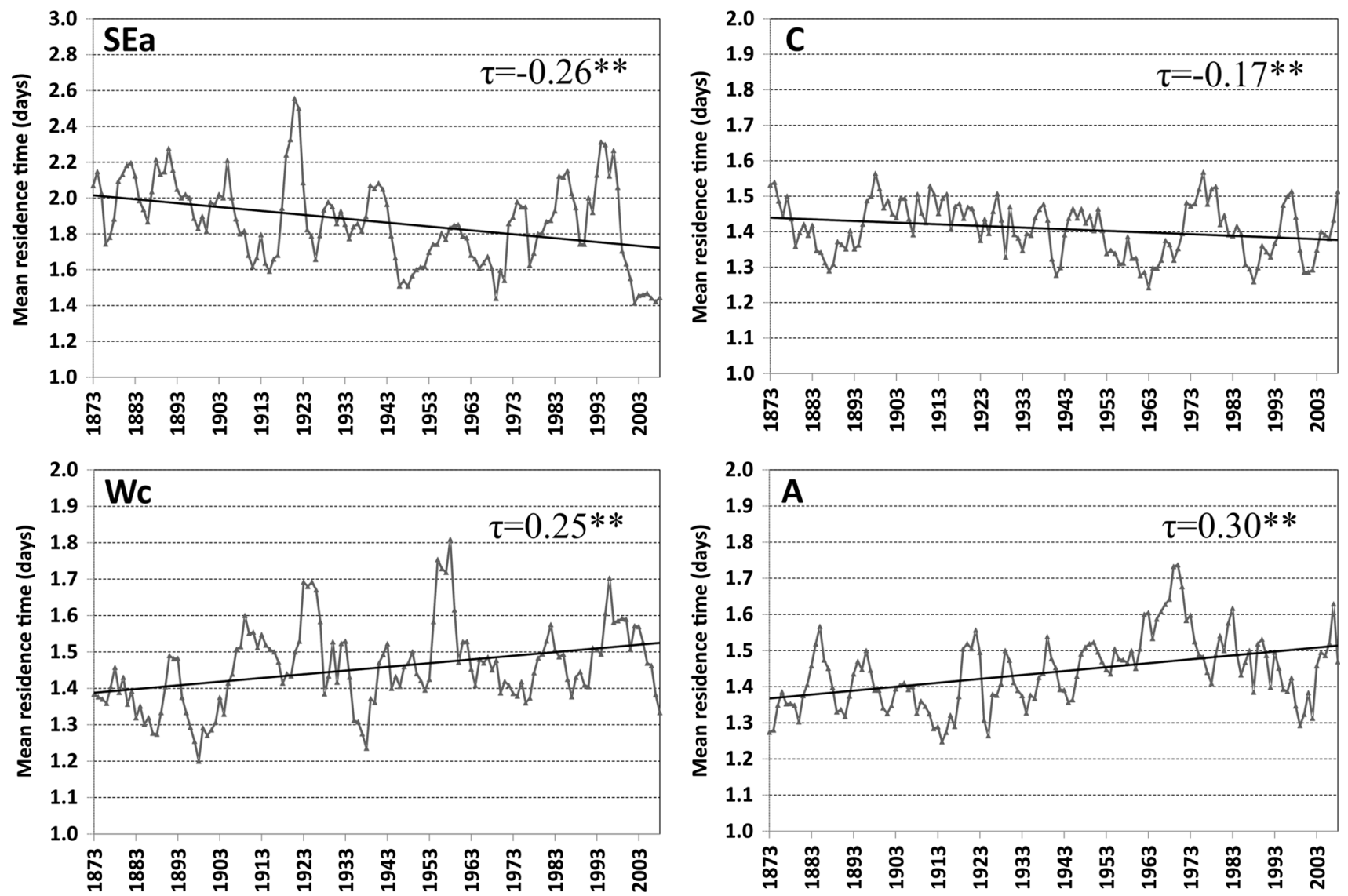

Fig. 9 Long-term changes in the mean residence time of four main circulation types in 1871-2010. Values are computed as averages over 5-year periods. *, **The level of significance for the Kendall's tau trend test, at $p<0.05, p<0.01$, respectively

air flow, and the number of days lower than the long-term mean was recorded from the mid twentieth century. The highest decrease in the frequency of days was observed in the 1950s and 1960s, amounting to approximately 4.0 days/10 years. From the mid-twentieth century, a decreasing contribution was also recorded in the case of southerly air flow with a minimum of frequency recorded in the last two decades of the analysed period. Its highest decrease was observed in the years 1981-2010, amounting to 4.4 days/10 years. The maximum frequency of days with southerly circulation occurred in the period from the first decade of the twentieth century to the mid 1930s. At the end of the twentieth century and at the beginning of the 21 st century, lower frequency also concerned days with south-westerly air flow. The maximum frequency was recorded at the turn of the 1930s and 1940s, and its strongest increase occurred in the period 1900-1929 (5.6 days/10 years). From the end of the 1970s to the beginning of the 21 st century, noticeably high positive anomalies occurred in the case of the number of days with westerly circulation (Fig. 10). Their considerable increase was recorded not only in the 1990s (4.6 days/10 years), but also in the 1920s and 1950s (5.6 and 4.0 years/10 years, respectively). The number of days with considerably lower than average westerly circulation was recorded in the years 1881-1910. Increased north-westerly circulation occurred in the 1970s and at the turn of the 1980s and 1990s. A considerably lower frequency was observed in the years 1910-1955.

From 1871 to 2010 , there was a statistically significant increase of the annual number of days with non-directional anticyclonic type A (Fig. 6), as well as types with westerly air flow, and directional anticyclonic types: $\mathrm{Na}$ and NEa. Cyclonic and transitional types experienced a statistically significant decrease in frequency, particularly in terms of south-easterly and southerly air flow. The most decreasing trends (both statistically significant and insignificant) were recorded for southerly air flow ( $>60 \%)$, while the highest contribution of increasing trends $(>70 \%)$ was related to westerly circulation.

Over East-Central Europe, there is strong relationship between frequency of western zonal circulation and winter (DJFM) North Atlantic Oscillation Index (Jones et al. 1997) (Table 3). During recent decades, a considerable increase in the strength of the correlation has been found (Fig. 11). One of the causes may be intensification of 

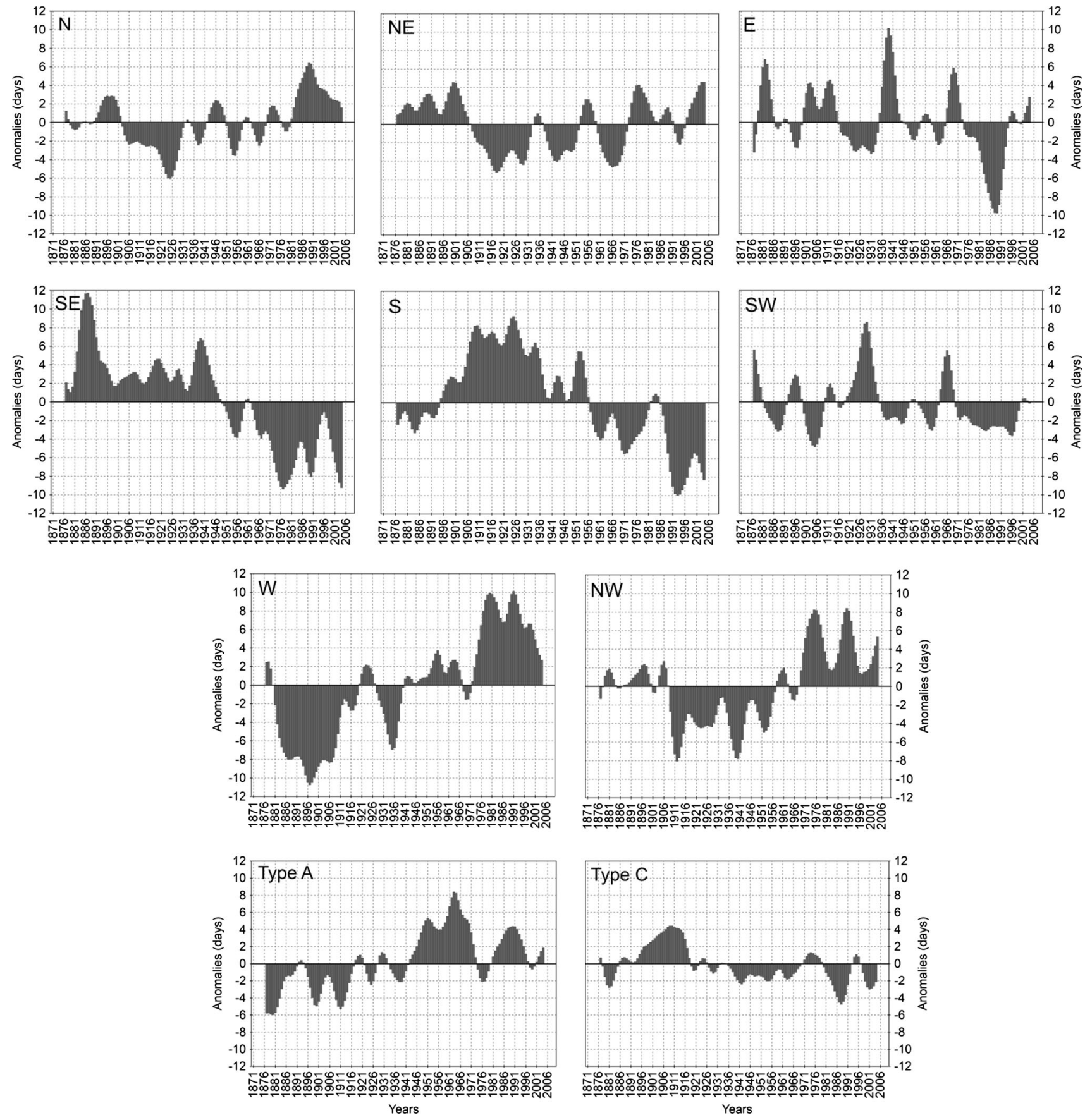

Fig. 10 Anomalies of annual number of days with different directions of air flow and non-directional CTs (i.e. type A and C) from 1871 to 2010. Values smoothed by 13-element Gaussian filter

western zonal circulation due to an eastward shift of the position of the centre of the Icelandic Low and Azores High in the period from December to February (Hilmer and Jung 2000; Johnson et al. 2008).

There was also observed the significant positive deviation of mean annual temperature in all of the years from the late 1990s to 2010 (not shown). At the same time, in winter, an increase in frequency of days was recorded with westerly and north-westerly circulation (3.3 and 2.5 days/ 10 years, respectively), while decreased with south-easterly and southerly (2.1 and 2.4 days/10 years, respectively). An upward trend in mean annual air temperature may also be partly associated with an increase in the frequency of days with easterly circulation in summer ( 3.5 days $/ 10$ years), as well as a decrease with westerly circulation patterns (2.0 days/10 years). In the case of 
Table 3 Pearson's linear correlation coefficients $(n=140)$ between the NAO index (DJFM) and frequency of air flow direction, as well as nondirectional circulation types over East-Central Europe from December to March

\begin{tabular}{|c|c|c|c|c|c|c|c|c|c|}
\hline \multicolumn{8}{|c|}{ Air flow direction } & \multicolumn{2}{|c|}{ Non-directional circulation types } \\
\hline $\mathrm{N}$ & $\mathrm{NE}$ & $\mathrm{E}$ & SE & $\mathrm{S}$ & SW & W & NW & A & $\mathrm{C}$ \\
\hline 0.04 & $-0.22 *$ & $-0.47 * *$ & $-0.42 * *$ & $-0.23 *$ & $0.26 *$ & $0.55^{* *}$ & $0.43 * *$ & -0.04 & $-0.38 * *$ \\
\hline
\end{tabular}

*,** Significant at $p<0.01, p<0.001$, respectively

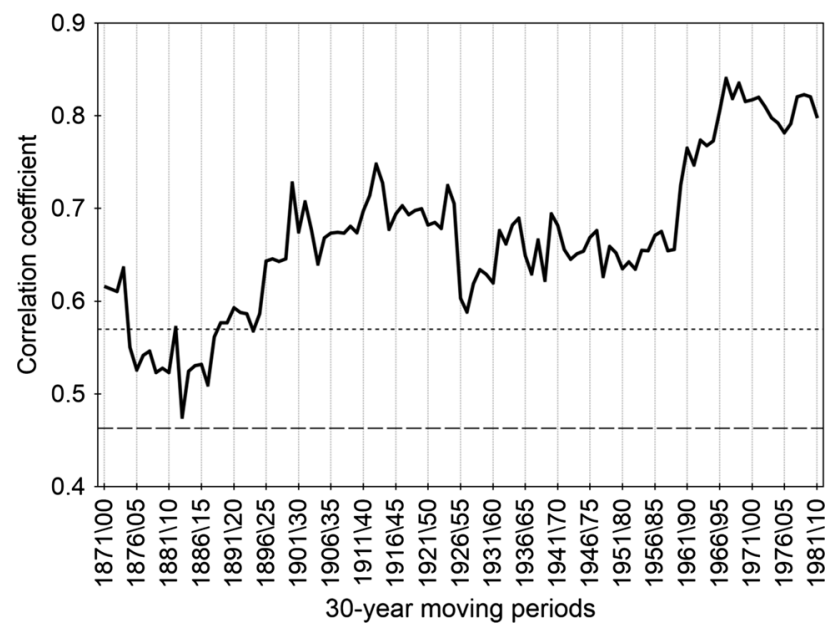

Fig. 11 Long-term variability of linear correlation coefficients for each of the 30-year moving periods between the NAO index (average of DJFM values) and the frequency of westerly air flow $(\mathrm{SW}+\mathrm{W}+\mathrm{NW})$ from December to March. Horizontal dotted lines indicate significant correlation at a $p$ value of 0.001 ; horizontal dashed lines at a $p$ value of 0.01

precipitation, there were no statistically significant trends from 1951 to 2010 .

\section{Discussion}

A number of studies show the occurrence in the area of Europe of two maximums of frequency of days with zonal westerly air flow in a year. The first one occurs in December and January, and the less evident second maximum is recorded in Central Europe in July and August (Keevallik et al. 1999; Hoy et al. 2012), as well as in East and North Europe from September to October (Chen 2000; Sepp and Jaagus 2002). In East-Central Europe, the second maximum is more evident in autumn, when the frequency of days with south-westerly advection is higher than in summer. Moreover, analogically as in North and NorthWest Europe (Chen 2000; Linderson 2001; Anagnostopoulou et al. 2004), a high contribution of easterly circulation is recorded in spring, as well as increased frequency of air flow from the northern directions in summer. Over East-Central Europe, similarly as in south Scandinavia (Linderson 2001), the highest contribution of the non-directional cyclonic type in a year occurs in spring, and in the case of the non-directional anticyclonic type, the maximum annual number of days occurs in summer, as also determined in West Europe (Anagnostopoulou et al. 2004).

In the last two decades of the nineteenth century and in the early twentieth century, the lowest frequency of westerly, and the highest frequency of easterly advection from 1871 to 2010 were recorded over East-Central Europe. A period of decreased westerly circulation was also recorded over the area of North Atlantic (Makrogiannis et al. 1982; Rogers 1984). In the following years (1910-1930), a significant increase in the frequency of southerly, southwesterly, and westerly air flow and number of days with non-directional cyclonic type were observed over EastCentral Europe. The occurrence in the period of strong zonal circulation and increased cyclonicity in the area of North Atlantic and West Europe was confirmed by Slonosky et al. (2000), Hurrell (1995), Parker et al. (1994), and Makrogiannis et al. (1982). In the 1930s and 1940s, a considerably lower number of days with westerly advection occurred again, as also confirmed in the study results by Slonosky et al. (2000). From approximately 1970 until the mid 1990s, a very evident increase in the frequency of westerly and north-westerly air flow was observed. An increase in zonal westerly circulation in the European-Atlantic area, particularly in winter, has been the subject of a number of studies (e.g., Rogers 1984; Bárdossy and Caspary 1990; Hurrell 1995; Keevallik et al. 1999; Werner et al. 2000; Kyselý and Huth 2006). The turn of the 1980s and 1990s was also a period with very high negative anomalies of easterly, south-easterly, and southerly circulation. By the end of the twentieth century, however, a considerable increase in frequency of days with easterly air flow over East-Central Europe had been recorded.

The obtained study results were compared to the subjective classification of CTs for South Poland, referring to the years 1873-2010 (Niedźwiedź 1981, 2013). The similarities, except for the winter maximum of frequency of zonal westerly circulation, include low mean annual frequency of northerly and north-easterly air flow, and the 
occurrence of the summer maximum number of days with anticyclonic type. The differences include considerably lower frequency (in the Niedźwiedź classification scheme) of days with southerly and south-easterly air flow in the spring period. The considerable contribution of easterly and south-easterly air flow in April and May was shown by the objective classification of CTs for Poland by Piotrowski (2009). Other similarities with the classification include the considerable contribution of circulation from the northern sector, and low contribution from the southern sector from June to August, high frequency of westerly and southwesterly air flow in autumn and winter, and a very similar annual number of days with non-directional undefined type (maximum in summer, and minimum in winter).

\section{Conclusions}

According to the study results, atmospheric circulation over East-Central Europe is distinguished by a relatively high annual variability. A change in the geographical location and spatial dimensions of the two principal centres of action in the atmosphere circulation of the Northern Hemisphere, i.e., the Icelandic Low and the Azores High, has a considerable influence on the frequency of CTs in this part of the continent. The result of the co-occurrence of both of the systems is observed over East-Central Europe in winter (dominance of south-westerly and westerly air flow), and the effect of the Azores High in the summer period (maximum of the number of days with non-directional anticyclonic type and considerable frequency of northerly air flow). The characteristic features of atmospheric circulation in the study area include the prevalence of easterly circulation and high contribution of the number of days with non-directional cyclonic type in April and May, as well as low frequency of southerly air flow in summer. The annual number of days with an undefined non-directional type is also characteristic. The extremely low frequency in winter months is associated with high changes in the pressure field as opposed to the summer period, when no large horizontal temperature or pressure gradients are observed over Europe.

The variability of atmospheric circulation on the multiannual scale is confirmed by the occurrence of periods with considerable positive or negative variation from the longterm mean of the number of days with a given circulation type. In the period 1871-2010, a statistically significant increase in frequency occurred in the case of westerly circulation and days with a non-directional anticyclonic type. A decrease occurred in the case of number of days with advection from the southern sector. The substantial variability of atmospheric circulation in this part of the continent is suggested by the relatively short persistence of circulation types. The longest persistence concerned situations of persistence of a high pressure system over North, North-East, or East Europe (types Ea, SEa and Sa).

Directional transitional types reflected a relatively frequent occurrence in this part of the continent of synoptic situations in which air flow is affected by both high and low pressure systems. The designation of the transitional class also contributed to the identification of situations in which air flow was related to strong cyclonic or anticyclonic circulation. In comparison to the two-class system (only including the cyclonic and anticyclonic class), such an approach should permit a more detailed assessment of the effect of the pressure system on the values of air temperature and precipitation. Therefore, in the case of designation directional CTs over East-Central Europe, the application of the three-class system is justified.

Acknowledgments The author would like to thank the anonymous reviewers for their valuable comments and suggestions to improve quality of the paper.

Open Access This article is distributed under the terms of the Creative Commons Attribution 4.0 International License (http://crea tivecommons.org/licenses/by/4.0/), which permits unrestricted use, distribution, and reproduction in any medium, provided you give appropriate credit to the original author(s) and the source, provide a link to the Creative Commons license, and indicate if changes were made.

\section{References}

Anagnostopoulou C, Flocas H, Maheras P, Patrikas I (2004) Relationship between atmospheric circulation types over Greece and western-central Europe during the period 1958-97. Int J Climatol 24:1745-1758. doi:10.1002/joc.1111

Bárdossy A, Caspary HJ (1990) Detection of climate change in Europe by analyzing European atmospheric circulation patterns from 1881 to 1989. Theor Appl Climatol 42(3):155-167. doi:10. 1007/BF00866871

Bartoszek K, Węgrzyn A (2011) The circulation conditions of the vegetation season beginning in eastern Poland. Ann Univ Mariae Curie Skłodowska Sec B 66(1):93-102 (in Polish)

Baur F (1937) Introduction in Grosswetter research. Verlag BG Teubner, Leipzig, p 51 (in German)

Bednorz E (2002) Snow cover in western Poland and macro-scale circulation conditions. Int J Climatol 22(5):533-541. doi:10. 1002/joc. 752

Blöschl G, Nester T, Komma J, Parajka J, Perdigão RAP (2013) The June 2013 flood in the Upper Danube basin, and comparisons with the 2002, 1954 and 1899 floods. Hydrol Earth Syst Sci 17:9533-9573. doi:10.5194/hess-17-5197-2013

Buishand A, Brandsma T (1997) Comparison of circulation classification schemes for predicting temperature and precipitation in The Netherlands. Int J Climatol 17(8):875-889. doi:10.1002/ (SICI)1097-0088(19970630)17:8<875:AID-JOC164>3.0.CO;2$\mathrm{C}$

Chen D (2000) A monthly circulation climatology for Sweden and its application to a winter temperature case study. Int J Climatol 20(10):1067-1076. $10<1067$ :AID-JOC528>3.0.CO;2-Q 
Compo GP, Whitaker JS, Sardeshmukh PD, Matsui N, Allan RJ, Yin X, Gleason BE, Vose RS, Rutledge G, Bessemoulin P, Brönnimann S, Brunet M, Crouthamel RI, Grant AN, Groisman PY, Jones PD, Kruk M, Kruger AC, Marshall GJ, Maugeri M, Mok HY, Nordli $\varnothing$, Ross TF, Trigo RM, Wang XL, Woodruff SD, Worley SJ (2011) The twentieth century reanalysis project. Q J R Meteorol Soc 137(654):1-28. doi:10.1002/qj.776

Demuzere M, Werner M, van Lipzig NPM, Roeckner E (2009) An analysis of present and future ECHAM5 pressure fields using a classification of circulation patterns. Int $\mathrm{J}$ Climatol 29(12):1796-1810. doi:10.1002/joc.1821

Esteban P, Martin-Vide J, Mases M (2006) Daily atmospheric circulation catalogue for Western Europe using multivariate techniques. Int J Climatol 26(11):1501-1515. doi:10.1002/joc. 1391

Falarz M (2007) Snow cover variability in Poland in relation to the macro- and mesoscale atmospheric circulation in the twentieth century. Int J Climatol 27(15):2069-2081. doi:10.1002/joc.1505

Girs AA (1971) Many-year fluctuations of atmospheric circulation and long-term hydro-meteorological forecasts. Leningrad, Gidrometeotzdat, p 280 (in Russian)

Goodess CM, Palutikof JP (1998) Development of daily rainfall scenarios for southeast Spain using a circulation-type approach to downscaling. Int J Climatol 18(10):1051-1083. doi:10.1002/ (SICI)1097-0088(199808)18:10<1051:AID-JOC304>3.0.CO;2-

Haylock MR, Hofstra N, Klein Tank AMG, Klok EJ, Jones PD, New M (2008) A European daily high-resolution gridded dataset of surface temperature and precipitation. J Geophys Res. doi:10. 1029/2008JD10201

Hess P, Brezowsky H (1977) Catalogue of European Grosswetterlagen. Deutscher Wetterdienst, Berichte des Deutschen Wetterdienstes 15(113), Offenbach, p 68 (in German)

Hilmer M, Jung T (2000) Evidence for a recent change in the link between the North Atlantic Oscillation and Arctic sea ice export. Geophys Res Lett 27(7):989-992. doi:10.1029/1999GL010944

Hoy A, Jaagus J, Sepp M, Matschullat J (2012) Spatial response of two European atmospheric circulation classifications (data from 1901 to 2010). Theor Appl Climatol 112(1-2):73-88. doi:10. 1007/s00704-012-0707-x

Hoy A, Sepp M, Matschullat J (2013) Atmospheric circulation variability in Europe and northern Asia (1901-2010). Theor Appl Climatol 113(1-2):105-126. doi:10.1007/s00704-0120770-3

Hurrell JW (1995) Decadal trends in the North Atlantic oscillation. Regional temperature and precipitation. Science 269:676-679. doi:10.1126/science.269.5224.676

Hurrell JW, Kushnir Y, Ottersen G, Visbeck M (2003) An overview of the North Atlantic Oscillation In: Hurrell JW, Kushnir Y, Ottersen G, Visbeck M (eds) The North Atlantic oscillation: climatic significance and environmental impact. American Geophysical Union, Washington DC, pp 1-35. doi:10.1029/ 134GM01

Huth R (1996) Properties of the circulation classification scheme based on the rotated principal component analysis. Meteorol Atmos Phys 59(3-4):217-233. doi:10.1007/ BF01030145

Huth R, Beck C, Andreas P, Demuzere M, Ustrnul Z, Cahynova M, Kyselý J, Tveito OE (2008) Classifications of atmospheric circulation patterns: recent advances and applications. Ann N Y Acad Sci 1146:105-152. doi:10.1196/annals.1446.019

Jenkinson AF, Collinson FP (1977) An initial climatology of gales over the North Sea. Meteorological Office, Synoptic climatology branch memorandum 62, Bracknell, p 18

Johnson NC, Feldstein SB, Trembley B (2008) The continuum of Northern Hemisphere teleconnection patterns and a description of the NAO shift with the use of self-organizing maps. J Clim 21(23):6354-6371. doi:10.1175/2008JCLI2380.1

Jones PD, Hulme M, Briffa KR (1993) A comparison of Lamb circulation types with an objective classification scheme. Int $\mathrm{J}$ Climatol 13(6):655-663. doi:10.1002/joc.3370130606

Jones PD, Jonsson T, Wheeler D (1997) Extension to the North Atlantic Oscillation using early instrumental pressure observations from Gibraltar and South-West Iceland. Int J Climatol 17(13):1433-1450. doi:10.1002/(SICI)1097-0088(19971115)17: 13<1433:AID-JOC203>3.0.CO;2-P

Jones PD, Harpham C, Briffa KR (2013) Lamb weather types derived from reanalysis products. Int J Climatol 33(5):1129-1139. doi: $10.1002 /$ joc. 3498

Kaszewski BM (2001) Applying the typology of atmospheric circulation to climatic investigations. Roczn Fizycznogeogr 6:13-26 (in Polish)

Kaszewski BM (2012) The application of the atmospheric circulation typology in climatological studies in Poland in the early twentyfirst century. In: Bielec-Bạkowska Z, Łupikasza E, Widawski A (eds), The role of atmospheric circulation in shaping the climate, UŚ, Sosnowiec, pp 53-66 (in Polish)

Kaszewski BM, Filipiuk E (2003) Variability of atmospheric circulation in Central Europe in the summer season 1881-1998 (on the basis of the Hess-Brezowski classification). Meteorol Z 12(3):123-130. doi:10.1127/0941-2948/2003/0012-0123

Keevallik S, Post P, Tuulik J (1999) European circulation patterns and meteorological situation in Estonia. Theor Appl Climatol 63(1-2):117-127. doi:10.1007/s007040050097

Kendall MG (1975) Rank correlation measures. Charles Griffin, London, p 202

Kyselý J (2007) Implications of enhanced persistence of atmospheric circulation for the occurrence and severity of temperature extremes. Int J Climatol 27(5):689-695. doi:10.1002/joc.1478

Kyselý J, Domonkos P (2006) Recent increase in persistence of atmospheric circulation over Europe: comparison with long-term variations since 1881. Int J Climatol 26(4):461-483. doi:10. $1002 /$ joc. 1265

Kyselý J, Huth R (2006) Changes in atmospheric circulation over Europe detected by objective and subjective methods. Theor Appl Climatol 85(1-2):19-36. doi:10.1007/s00704-005-0164-x

Lamb HH (1972) British Isles weather types and a register of daily sequence of circulation patterns, 1861-1971. HMSO, Geophysical Memoir 116, London, p 85

Lewis AB, Keim BD (2015) A hybrid procedure for classifying synoptic weather types for Louisiana, USA. Int J Climatol 35(14):4247-4261. doi:10.1002/joc.4283

Linderson MJ (2001) Objective classification of atmospheric circulation over Southern Scandinavia. Int J Climatol 21(2):155-169. doi:10.1002/joc.604

Lityński J (1969) A numeral classification of circulation and weather types for Poland. Pr PIHM 97:3-15 (in Polish)

Łupikasza E (2010) Relationships between occurrence of high precipitation and atmospheric circulation in Poland using different classifications of circulation types. Phys Chem Earth 35(9-12):448-455. doi:10.1016/j.pce.2009.11.012

Makrogiannis TJ, Bloutsos AA, Giles BD (1982) Zonal index and circulation change in the North Atlantic area, 1873-1972. J Climatol 2(2):159-169. doi:10.1002/joc.3370020206

Niedźwiedź T (1981) Synoptic situations and their influence on spatial differentiation of the selected climate elements in the Upper Vistula Basin. UJ, Rozpr hab UJ 58, Kraków, pp 165 (in Polish)

Niedźwiedź T (2013) Calendar of circulation types, air masses and fronts for Southern Poland. Department of Climatology, University of Silesia: Sosnowiec. http://klimat.wnoz.us.edu.pl. Accessed 18 May 2014 
Nowosad M (2004) Circulation seasons over Poland (1951-1990). Ann Univ Mariae Curie Skłodowska Sec B 59(5):83-100 (in Polish)

Osborn TJ (2006) Recent variations in the winter North Atlantic oscillation. Weather 61(12):353-355. doi:10.1256/wea.190.06

Osuchowska-Klein B (1978) The catalogue of atmospheric circulation types. Warszawa, WKiŁ, p 192 (in Polish)

Parker DE, Jones PD, Folland CK, Bevan A (1994) Interdecadal changes of surface temperature since the late nineteenth century. J Geophys Res 99(D7):14373-14399. doi:10.1029/94JD00548

Piotrowski P (2009) An objective method of classification of atmospheric circulation for Poland. Wyd UŁ, Fol Geograph Phys 10, Łódź, p 216 (in Polish)

Post P, Truija V, Tuulik J (2002) Circulation weather types and their influence on temperature and precipitation in Estonia. Boreal Environ Res 7(3):281-289

Rogers JC (1984) The association between the North Atlantic Oscillation and the Southern Oscillation in the Northern Hemisphere. Mon Wea Rev 112:1999-2015. doi:10.1175/15200493(1984)112<1999:TABTNA > 2.0.CO;2

Schädler G, Sasse R (2006) Analysis of the connection between precipitation and synoptic scale processes in the eastern Mediterranean using self-organizing maps. Meteorol Z 15(3):273-278. doi:10.1127/0941-2948/2006/0105

Sen PK (1968) Estimates of the regression coefficient based on Kendall's tau. J Am Stat Assoc 63(324):1379-1389. doi:10. $2307 / 2285891$

Sepp M, Jaagus J (2002) Frequency of circulation patterns and air temperature variations in Europe. Boreal Environ Res 7(3):273-279

Slonosky VC, Jones PD, Davies TD (2000) Variability of the surface atmospheric circulation over Europe, 1774-1995. Int J Climatol 20(15):1875-1897. doi:10.1002/1097-0088(200012)20: 15<1875:AID-JOC593>3.0.CO;2-D

Stehlík J, Bárdossy A (2003) Statistical comparison of European circulation patterns and development of a continental scale classification. Theor Appl Climatol 76(1-2):31-46. doi:10.1007/ s00704-003-0007-6

Trigo RM, Da Camara CC (2000) Circulation weather types and their influence on the precipitation regime in Portugal. Int J Climatol 20(13):1559-1581. doi:10.1002/1097-0088(20001115)20: 13<1559:AID-JOC555>3.0.CO;2-5

Ustrnul Z (1997) Variability of the Atmospheric Circulation on the Northern Hemisphere in the 20th century. Mat Bad IMGW, Ser Meteorol 27, Warszawa, p 208 (in Polish)

Ustrnul Z (2006) Spatial differentiation of air temperature in Poland using circulation types and GIS. Int $\mathrm{J}$ Climatol 26(11):1529-1546. doi:10.1002/joc.1393

Ustrnul Z, Czekierda D, Wypych A (2010) Extreme values of air temperature in Poland according to different atmospheric circulation classifications. Phys Chem Earth 35(9-12):429-436. doi:10.1016/j.pce.2009.12.012

Vangengeim GJ (1935) Experimental usage of synoptical metods for studying and characterizing of climate. Gidrometeotzdat, Moskva, p 109 (in Russian)

Werner PC, Gerstengarbe FW (2010) Catalogue of European Grosswetterlagen. Potsdam-Institut für Klimafolgenforschung, PIK-Report, 119, Potsdam, p 140 (in German)

Werner PC, Gerstengarbe FW, Fraedrich K, Oesterle H (2000) Recent climate change in the North Atlantic/European sector. Int J Climatol 20(5):463-471. doi:10.1002/(SICI)10970088(200004)20:5<463:AID-JOC483>3.0.CO;2-T

Yarnal B (1993) Synoptic climatology in environmental analysis. Belhaven Press, London, p 195

Zhang X, Wang XL, Corte-Real J (1997) On the relationships between daily circulation patterns and precipitation in Portugal. J Geophys Res 102(D12):13495-13507. doi:10.1029/97JD01012

Żmudzka E (2007) The variability of cloud cover over Poland and determinants of its circulation (1951-2000). Wyd UW, Warszawa, p 399 (in Polish) 